\title{
Correction to: Decomposing supply-side and demand-side impacts of climate change on the US electricity system through 2050
}

\author{
Daniel C. Steinberg ${ }^{1}$ (D) Bryan K. Mignone ${ }^{2} \cdot$ Jordan Macknick $^{1} \cdot$ Yinong Sun $^{1} \cdot$ \\ Kelly Eurek ${ }^{1} \cdot$ Andrew Badger $^{3} \cdot$ Ben Livneh $^{3,4} \cdot$ Kristen Averyt $^{5}$
}

Published online: 22 October 2020

(C) ExxonMobil Research and Engineering Company, The National Renewable Energy Laboratory 20202020

\section{Correction to: Climatic Change \\ https://doi.org/10.1007/s10584-019-02506-6}

The article "Decomposing supply-side and demand-side impacts of climate change on the US electricity system through 2050", written by Daniel C. Steinberg, Bryan K. Mignone, Jordan Macknick, Yinong Sun, Kelly Eurek, Andrew Badger, Ben Livneh, Kristen Averyt, was originally published electronically on the publisher's internet portal on 3 January 2020 without open access.

The article is forthwith distributed under a Creative Commons Attribution 4.0 International License (https://creativecommons.org/licenses/by/4.0/), which permits use, sharing, adaptation, distribution and reproduction in any medium or format, as long as you give appropriate credit to the original author(s) and the source, provide a link to the Creative Commons licence, and indicate if changes were made.

The online version of the original article can be found at https://oi.org/10.1007/s10584-019-02506-6

Daniel C. Steinberg

daniel.steinberg@nrel.gov

1 National Renewable Energy Laboratory, Golden, CO 80401, USA

2 ExxonMobil Research and Engineering Company, Annandale, NJ 08801, USA

3 Cooperative Institute for Research in Environmental Sciences, University of Colorado Boulder, Boulder, CO 80309, USA

4 Department of Civil, Environmental, and Architectural Engineering, University of Colorado Boulder, Boulder, CO 80309, USA

5 Desert Research Institute, Las Vegas, NV 89119, USA 
Open Access This article is licensed under a Creative Commons Attribution 4.0 International License, which permits use, sharing, adaptation, distribution and reproduction in any medium or format, as long as you give appropriate credit to the original author(s) and the source, provide a link to the Creative Commons licence, and indicate if changes were made. The images or other third party material in this article are included in the article's Creative Commons licence, unless indicated otherwise in a credit line to the material. If material is not included in the article's Creative Commons licence and your intended use is not permitted by statutory regulation or exceeds the permitted use, you will need to obtain permission directly from the copyright holder. To view a copy of this licence, visit http:// creativecommons.org/licenses/by/4.0/. 